\title{
Die teologiese debat: Die waarde \\ of betekenis daarvan
}

\section{A D Pont \\ Universiteit van Pretoria}

\begin{abstract}
The theological debate: Its value and significance

With negotiation and debate being the buzz-words of our day, it is of some value to explore, even if only superficially, the structure and tendency of the theological debate in the history of the church. In the theological debate the cardinal issue is the Word of God which determines the word of man. In this light the theological debate can be distinguished as both an internal debate within the chunch and an external debate with those outside the church. The substance of the debate is determined largely by the question of the content and significance of the Word of God. Since the Word of God is an absolute norm, the theological debate tends to become a statement and, in many cases, does not develop into an exchange of ideas or points of view. The theological debate, with its apologetic, explanatory and didactic elements, is however a necessary element in church life. Within its limits it can be a stimulating expression of the faith of the church.
\end{abstract}

Sic non scribit, qui rem perspecit et recte intelligit. Ego vero hoc libro non contuli sed asservi et assero, ac penes nullum volo esse iudicium, sed omnibus suadeo, ut praestent obsequium.

(M Luther, De servo arbitrio, 1525)

\section{INLEIDING}

In ons dae is dit hoe mode om oor alles debat te voer. Een van die towerwoorde van ons tyd, veral op die politiek-staatkundige terrein, is onderhandeling of gesprekvoering. Dit is dan 'n gesprek of debat om allereers gemeenskaplike grond tus-

- Referaal gelewer by die kongres van die Kerkhistoriese Genootskap van die Nederduitsch Hervormde Kerk, Pretoria, November 1993. 
sen die deelnemers vas te stel. Daarvandaan word verder gegaan om, sodra gemeenskaplike grond gevind is, die hoogste mate van ooreenstemming te bereik. Op die manier word probeer om, op die politiek-staatkundige terrein, botsings tussen uiteenlopende ideologieë en beleidsrigtings te vermy en vreedsame oplossings vir probleme te kry. Vir die doel is selfs 'n uitgebreide tegniek van onderhandeling of gesprekvoering uitgewerk. Dat hierdie soort debat of onderhandeling die resultaat van 'n bepaalde soort beleid of verstaan van die werklikheid is, is nie nou ter sake nie (Marais 1983:98).

Indien nou, in die lig hiervan, 'n vraag gestel word oor die teologiese debat, sy aard, sy waarde en betekenis dan word dit dadelik duidelik dat die teologiese debat eiesoortig is. Dit dan in dié sin dat die oorsprong van die debat buite die mens self lê. Volgens die Heilige Skrif is dit die Here God wat die mens, die skepsel van sy hand, aanspreek en tot geloof, gehoorsaamheid en diens oproep. Daardie Woord kom van buite af, gesaghebbend en absoluut, na die mens toe.

Die mens wat dié Woord hoor, verstaan, verwerk en interpreteer op sy beurt daardie Woord. Daaruit vloei die teologiese debat of gesprek in en om die kerk voort, dit wil sê die gesprek oor die inhoud, die draagwydte en die grense van daardie Woord. Die spreke van die lewende God wat tot die mens gerig is, roep nie net die antwoord aan God na vore nie, maar ook 'n lewendige gesprek onder die mense. Daardie gesprek van die mense oor die boodskap of spreke van God, word bepaal deur die primêre Woord van God.

So gesien is die teologiese debat of gesprek so oud soos die kerk self. Dit omdat dit in die kerk primêr gaan om daardie Woord van God wat na die mens toe kom en van die mens nie net geloof en gehoorsaamheid vra nie maar ook diensbaarheid, wat beteken dat hy daardie woord verder moet dra. Daar was, aanvanklik, geen ander doeltreffende manier om die boodskap van God wyd uit te dra as deur die gesproke woord nie. Dit omdat die geskrewe woord 'n beperkte verspreidingsmoontlikheid gehad het. Die woord of boodskap wat deur die kerk uitgedra is, het, uit die aard van die saak, antwoorde uitgelok en so het die teologiese gesprek as vanself deel van die lewe van die kerk geword. Die karakter van die gesprek kan in die begin aangedui word as die poging om die boodskap wat gebring moet word

- positief uit een te sit;

- dit verder te verklaar en te omskryf; en

- dit, indien nodig, te verdedig teen die bedenkinge wat daarteen ingebring mag word.

Hoewel die debat nie altyd 'n vaste en formele struktuur gehad het nie, was dit steeds daarop gemik om die hoorder te oorreed om die boodskap te aanvaar en daarmee in te stem. Omdat die kerk oortuig is dat die boodskap wat gebring word 
'n absolute waarheid is, omdat dit ' $n$ boodskap van die lewende God is, het die boodskap ook 'n bepaalde absolute karakter gehad wat nie teenspraak aanvaar het nie. Andersyds het dit beteken dat die draers van die boodskap nie bereid was om aanpassings of toegewings ten opsigte van die inhoud van die boodskap te aanvaar nie. Dit het vanselfsprekend tot botsings gelei want daar was nie 'n moontlikheid om 'oplossings' in die debat, in die sin van kompromieë, te aanvaar nie. In die kerk self was daar buitendien van die begin af 'n bepaalde rem wat verhoed het dat kompromieë gemaak of veranderings aangebring kan word ten opsigte van die sentrale inhoud van die boodskap.

As dit gestel word dan kan verder gesê word dat die teologiese debat, in en om die kerk, van die begin af in twee soorte gesprekke onderskei kan word. Aan die een kant was daar die gesprek na binne, in die ruimte van die kerk self wat die bedoeling het om die inhoud en die draaguydte van die boodskap wat uitgedra moet word, uiteen te sit en te presieseer. Dit is, byvoorbeeld, binne die raamwerk van hierdie gesprek in die vroeë kerk, dat die kanon van die heilige Skrifte ontstaan om daarmee ook die inhoud en grense van die boodskap van die kerk te bepaal.

Aan die ander kant was daar die gesprek na buite, die gesprek om die boodskap, soos dit binne die kerk aanvaar is, te verduidelik, te omlyn of te verdedig teenoor diegene buite die kerk. Daarvan is Origines se debat met Celsus, in die middel van die derde eeu, of Luther se debat met Erasmus uit die jare 1524-1525, tipiese voorbeelde.

Dit is egter duidelik dat die teologiese debat as 'n verskynsel 'n groter omvang het as slegs die gesprek na binne en na buite. Daarom is dit seker onmoontlik om binne die bestek van hierdie referaat, alles oor die teologiese debat te sê. Aan die ander kant is dit ook weer so dat hoe die struktuur of gestalte van die gesprek ook al omskryf word, die teologiese gesprek altyd draai om

- die leer van die kerk;

- die regte verstaan van die evangelie van Jesus Christus; en

- die inhoud van God se Woordopenbaring.

In dié debat, is soos reeds gesê, die Woord van God die onveranderlike. Hoewel dároor ook 'n verskil kan bestaan, soos blyk uit die voorbeeld van Marcion c 160, wat teenoor die kerk sy eie kanon van gesaghebbende Skrifte saamgestel het, bring dié element van ' $n$ absolute waarheid 'n bepaalde vasstaandheid in die teologiese debat. Dit het die gevolg dat die teologiese debat of gesprek soms nie verder vorder as die stel van 'n standpunt nie. Vloeibaarheid, kompromieë en toegewings is rondom die absolute Waarheid, wat die wentelpunt van die teologiese debat is, nie so maklik aanvaarbaar nie. Daarom is die deelnemers aan die teologiese debat dikwels eerder woordvoerders as gespreksgenote, soos blyk uit die briefwisseling 
tussen Sadoleto en Calvyn in die jaar 1539. Daarom kan gestel word dat die doel van die teologiese debat dikwels nie is om ooreenstemming te bereik nie, maar om te oorreed. Dan word die waarde van die teologiese debat, vir die beoordelaar van buite, wat die gesprek aanvaar as 'n middel om vanuit verskillende standpunte tot by 'n gemeenskaplike waarheid te kom, nogal betreklik.

In 'n poging om 'n paar groot lyne te trek oor hierdie saak, kan die volgende by wyse van oorsig en inleiding na vore gebring word.

\section{IETS OOR DIE AARD VAN DIE TEOLOGIE}

Voordat iets oor die debat in die teologie gesê word, is dit tog nodig om die aard van die teologie aan te dui. Dan is dit belangrik om daarop te let dat die teologie, in 'n sekere sin op 'n onveranderlike gebou is, dit wil sê op die gegewe Heilige Skrif wat 'n oorkonde van die openbaring van God is. Die feit dat die Heilige Skrif uniek is en sy uiteensetting nie deur die mens verander kan word nie, het, uit die aard van die saak, 'n direkte invloed op die teologie, sy inhoud en die teologiese debat. Dit dan veral in die kring van die reformatoriese teologie.

Met die aanvang van die kerkhervorming het Martin Luther in 1521, in sy antwoord aan die Ryksdal van Worms, dit skerp gestel dat hy net van mening kan verander indien hy '... deur die getuienis van die Skrif of deur klaarblyklike rede oortuig kan word, want...ek is gebonde deur die Skrifgetuienis' (Pont 1984:75). Daarmee karakteriseer Luther die kerkhervorming as 'n beweging wat niks anders wil verkondig nie as die Skrifgetuienis oor die verhouding van God, mens en wêreld nie. Dieselfde argument word teruggevind by al die kerkhervormers en eksplisiet by Calvyn (vgl die Geloofsbelydenis van Genève 1536, art 1).

Die stelling van Luther en die aanvaarding daarvan deur die kerkhervormers hang saam met die nuwe verstaan van die begrip geloof wat omskryf word as 'n genadegawe van God wat totale betrokkenheid van die gelowige, van sy hele lewe, denke, wil en gevoel op Jesus Christus, wat Hom deur die evangelie openbaar, meebring. Hierdie geloof leef en die gelowige spreek dit as vanselfsprekend uit (Heidelbergse Kategismus, Sondag 7).

In die raamwerk is teologie dan die wetenskaplike nadenke oor en formulering van die geloof van die gelowiges, of te wel die kerk. Dit is belangrik om in gedagte te hou dat daar 'n duidelike verband is tussen Heilige Skrif, geloof, teologie en kerk en dat die een sonder die ander 'n teenspraak in hornself inhou.

Dit is aanvanklik, met die begin van die kerkhervorming, voldoende dat Luther, Zwingli en Calvyn, om net die hooffigure te noem, al die nadruk lê op die evangelie, die Bybelse karakter van hulle boodskap. Dit word 'n standaard formulering om ál die klem te lê op die Heilige Skrif alleen as die enigste basis van geloofskennis (Jacobs 1959:105) en die teologie (Luther 15-18, Die Heidelberger Disputation, in Clemen 1963:375- 503). 
Indien die teologiese debat, soos die kerkhervormers dit gevoer het, vergelyk word met die van die vroeë kerk kom ' $n$ interessante parallel na vore. Dit dan so dat daar 'n boodskap is wat in die wêreld en teen die wêreld uitgedra word en wat nie 'n vanselfsprekende aanvaarding gehad het nie (Von Campenhausen 1956:10). Dié boodskap is, in beide gevalle, deur die beskikbare kommunikasiemiddele uitgedra, dit wil sê: mondeling en skriftelik. In daardie uitdra van die boodskap het die teologiese debat of gesprek 'n wesenlike rol gespeel.

Ter wille van die oorsigtelikheid sou die aard van die teologiese gesprek, soos dit in die vroeë kerk na vore gekom het, as volg aangedui kan word (Overbeck 1966:13-14):

- die demonstratio evangelica, of die verdediging van die geloof teen die heidendom, soos gevind in die Brief aan Diognetos;

* die demonstratio catholica, of die verduideliking en verdediging van die leer teen die afwykende mening in die kerk, soos in die Briewe van Ignatius;

* die uitleg van die Ou Testament om die samehang met die Nuwe-Testamentiese geskrifte aan te dui, soos in die Brief van Barnabas;

- die eerste pogings om 'n Christelike lewensorde vir die kerk te omlyn soos in die Briewe van Clemens Romanus;

- 'n kerkhistoriese uiteensetting in Ignatius se Brief aan die gemeente Smyrna;

* die begin van die uitleg van die Nuwe Testament in die fragment van Papias se geskrifte; en

- 'n poging om 'n Christelike sedeleer te omskryf soos in Hermas se Herder.

Feitlik dieselfde patroon kan vir die geskrifte van die kerkhervormers aangedui word, miskien met die verskil dat die uitleg van die Skrif, die eksegese en die prediking in sowel die mondelinge as skriftelike vorm, 'n groot persentasie van die totale aantal geskrifte uitmaak. Daarmee saam het die kerkhervormers met die eis om die Bybel in die volkstaal beskikbaar te stel daarin geslaag om die klankbord waarteen die teologiese gesprek gevoer is, aanmerklik te verbreed. Hiermee en met die beklemtoning van die volkskerk, het die kerkhervormers aan die nuwe beweging 'n groot lewensvatbaarheid gegee teenoor die roomse kerk wat sy universaliteit in 'n struktuur wou verwerklik (vgl van Niftrik 1953:274) en dit met dwang en geweld wou handhaaf.

Die teologiese debat in die tyd van die kerkhervorming het, struktureel gesproke, nie veel verskil van die basiese vorm daarvan soos dit in die vroeë kerk voorgekom het nie. Terwille van die oorsigtelikheid kan die debat in vier kategorieë ingedeel word. Dié is dan: 
* die afgrens na buite, die verdediging van die geloof teenoor die roomse kerk en sy teoloë, teenoor die roomse owerhede en die sektes;

* die verduideliking en uiteensetting van die geloof in die eie kring en die verdediging van die leer teen die afwykende menings in die kerk;

- die onderwysende gesprek, en

* die godsdiensgesprekke met roomse teoloë en owerheidspersone voor die Konsilie van Trente.

In al hierdie gevalle was dit so dat daar reeds ' $n$ bepaalde gemeenskaplike grond vir die debat was. Dit ook omdat die kerkhervormers nie 'n totaal nuwe leer of verstaan van die Skrif na vore gebring het nie maar slegs die dwalings van die roomse kerk in leer en lewe, wou hervorm. Dit het veral op twee punte skerp na vore gekom. Dit was enersyds in die verwerping van die roomse tradisie as 'n bron van kennis oor God en mens, naas die Skrif en andersyds in die roomse aanvaarding van die filosofie van Aristoteles as die filosofies-lewensbeskoulike onderbou van die boodskap van die Bybel (vgl Bernhart 1954:XXXIII-LXXX). Dié verwerping het meegebring dat die monnike-teologie en alles wat daarmee saamhang deur Luther vervang is met die leer van die reguerdiging deur die geloof alleen. Daardie leerstuk was vir die eerste stadium van die kerkhervorming die sentrale leerstuk waarom die reformatoriese teologie gedraai het (Graafland 1987:1). Dit het beteken dat daar vir die kerkhervormers, naas die gemeenskaplike soos byvoorbeeld uiteengesit in Calvyn se skrywe van 1536 aan koning Frans I (Simpson 1984:89), daar ook 'n aantal kernpunte was waaroor hulle, op grond van die Skrif, heeltemal met Rome verskil het en waaroor hulle geen toegewings sou maak nie. Dit het Luther baie duidelik aan Erasmus uitgespel in sy De servo arbitrio van 1525.

\section{DIE RESULTATE}

Indien die vraag na die resultate van die teologiese debat van die kerkhervormers gevra word, dan kan dit 'n baie wydlopende uiteensetting word. Dit is duidelik dat die kerkhervorming 'n enorme bydrae gelewer het om die Wes-Europese leefwêreld, soos dit tot 1517 bestaan het, te wysig. Dit is egter op die kerklike en teologiese gebied waar die kerkhervorming die grootste invloed gehad het. Dit blyk, onder andere, uit die groot getal geloofsbelydenisse wat tydens die kerkhervorming na vore kom.

Die geloofsbelydenisse het 'n vaste onderdeel van die teologiese debat gevorm. Dit is belangrike dokumente omdat dit, naas die geskrifte en standpunte van die teoloë, die gesamentlike, algemeen aanvaarde omskrywing van die geloof en geloofsoortuigings van die hervormde kerke was. Hoewel die geloofsbelydenisse dikwels begin as 'n uiteensetting van één man, word dit mettergaan aanvaar as 'n dokument wat die geloof van 'n kerklike gemeenskap uitdruk. 
In 'n uitvoerige studie het Augustyn (1969) ook op die plek en betekenis van die geloofsbelydenis in die teologiese debat van die $16^{\text {de }}$ en $17^{\mathrm{de}}$ eeu gewys. So was die aanvanklike geloofsbelydenis wat Zwingli opstel in 1523 'n poging om, vanuit die evangelie, eenheid in denke en handelinge in Zürich te verkry (Augustyn 1969:1113). Hierdie eerste Zürichse geloofsbelydenis, net soos die een wat Luther in 1528 opstel, wil vanuit die Skrif ' $n$ aantal teologiese vrae van die dag binne die eie kerklike kring, beantwoord. In die twee belydenisse is dit duidelik dat op daardie stadium die Skriftuurlike uitspraak die beslissende is en dat die geloofsbelydenis slegs 'n afgeleide gesag het in die sin dat dit die waarheid van die Skrif uitdruk.

Naas die, byna binne-kerklike, gebruik van die geloofsbelydenis kom in Lutherse Duitsland die geloofsbelydenis as 'n verdediging van die geloof en leer na vore. Die beste voorbeeld hiervan is die geloofsbelydenis, opgestel deur Melanchton in 1530, wat aan die Ryksdag van Augsburg voorgelê word. Die geloofsbelydenis is deel van 'n debat want Johannes Eck het, van roomse kant, 404 stellings teen die Lutherse leer en praktyk gepubliseer waarop Melanchton dan antwoord (Kidd 1911: 250-289). Die belydenis is dus bedoel vir die buitewêreld om, teenoor die roomse kerk en keiser, die geloof en teologie van die Lutherane te omlyn en te beskryf (Augustyn 1969:21). Die roomse antwoord op die geloofsbelydenis het Melanchton gedwing om nog 'n verdere Apologia op te stel om ook die aanval af te slaan. So gesien is die Augustana en sy Apologia nie suiwer geloofsbelydenisse nie, maar eerder gespreksdokumente oor die Lutherse leer op 'n bepaalde punt in die geskiedenis (Schaff 1919:225). Die aard van die omstandighede het meegebring dat hierdie gespreksdokumente geloofsbelydenisse geword het en algaande ook vanweë die landsomstandighede, politieke dokumente en daarna in 1555, by die ryksdag van Worms, ryksdokumente wat deel vorm van die cuius regio eius religio-reëling.

Tog het dit alles Calvyn nie verhinder om in $\mathbf{1 5 4 0}$ die Augsburgse geloofsbelydenis assodanig te aanvaar nie, al het hy bepaalde bedenkinge daarteen gehad. Die belangrike vir hom was dat dit uitdrukking van 'n bepaalde eenheid in die geloof was (Augustyn 1969:21).

In die binne-kerklike teologiese debat kom in die calvinistiese kerke veral die kategismus, die onderrig-boek vir die kinders, na vore as 'n opvoedingsmiddel om die gelowiges te leer om tussen die goeie, Bybelse leer en die afwykings te onderskei. Assodanig dui die kategismus ook die grense van die leer aan en presieseer die inhoud daarvan. Miskien meer as die ander soort geloofsbelydenisse het die calvinistiese kategismusse, en dan veral die Heidelbergse Kategismus, die eenheid in die leer wat daar by die calvinistiese kerke bestaan het, uitgedruk. Soos Augustyn (1969:32) dit stel: 'Het gaat niet om een geforceerde eenheid in de formulering van het belijden, maar om de eenheid in hoofdzaak van het belijden.' Dit was in die $16^{\text {de }}$ 
en 17 de eeu nie vreemd nie dat die calvinistiese kerke in die verskillende lande oor en weer mekaar se geloofsbelydenisse erken het om so uitdrukking aan die geloofseenheid van die kerk te gee. Mettergaan, wanneer die geloofsbelydenis in die skolastieke teologie na Calvyn 'n al selfstandiger rol, losser van die Skrif kry, verander hierdie opvatting en word die formulering belangriker as die saak. Die uiteinde is dat in ons dag kerklike eenheid weer, soos by Rome, struktureel verstaan word met daarby 'n ooreenstemming in die leer en iewe en nie, in die eerste plek, in die geloof nie (Aalders sa:15).

'n Duidelike voorbeeld van 'n teologiese debat wat gelei het tot die formulering van 'n belydenisskrif, is seker die debat oor die uitverkiesing in Nederland van die

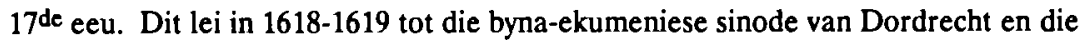
aanvaarding van die Dordtse Leerreëls. Dan kom daar, in die Nederlandse kerk, na die reël van die teologie van daardie tyd en na uitvoerige debatvoering, 'n verdere saak by. Dit is die stelling dat die belydenis nie net die onderlinge eenheid in die leer uitdruk nie maar ook die maatstaf word vir die suiwerheid van die leer in die kerk. 'n Saak wat dan veral deur die proponentsformule gereël word.

Langs hierdie vorm van teologiese debat, was daar ook uitvoerige debatte tussen teoloë en hier kan verwys word na die debat van Erasmus en Luther oor die saak van die vrye wil van die mens in die jare 1524-1525 (Pont 1983:102-105). Dan Luther se bekende gesprek met Zwingli te Marburg in 1529.

Daarby kan genoem word Calvyn se debat met Sadoleto in 1539 wat nogal verstrekkende gevolge vir Calvyn, die saak van die protestantisme en Genève gehad het (Olin 1966). Ook van meer as gewone belang was Calvyn se debat met Pighius in 1542 oor die vrye wil (Schulze 1971).

Verder kan ook nog verwys word na die uitvoerige, gewoonlik persoonlike gesprekke waaraan Calvyn en ander kerkhervormers deelgeneem het om te sien of ooreenkomste met Rome bereik kon word. Daarby kom dan ook sy gedagtewisselings met Lutherane, Zwingliane en ander. Telkens in hierdie gesprekke word dit duidelik dat dit vir Calvyn net om een, allesoorheersende saak gaan: die pura doctrina, wat vir hom beteken: die Woord van God, die suiwer evangelie, die leer van die heilige Skrif (Nijenhuis 1959:234-248).

As die saak van die teologiese debat wat gedurende die $16^{\text {de }}$ en $17^{\text {de }}$ eeu so wyd geloop het, saamgevat word dan kan gestel word: die debat wat na buite en binne gevoer is, wat apologetiese, tetiese en didaktiewe elemente vertoon en wat sowel skriftelik as mondeling gevoer is, was die manier waarop die groot teoloë van die kerkhervorming en hulle ondersteuners die saak van die suiwer, Bybelse evangelie gevestig en verbrei het. Dat hulle soveel sukses gehad het, was enersyds te danke aan hulle vermoë om hulle saak met krag en oortuiging te stel. Andersyds was die 
nuwe uitvinding en tegniek van die boekdrukkuns die een middel gewees waardeur hulle gedagtes en opvattings wyd oor Europa versprei kon word. Sodoende het hulle invloed baie ver gereik en was dit moontlik dat Wittenberg, Genève en ander protestantse universiteite ' $n$ toeloop van studente getrek het wat op hulle beurt weer die boodskap verder kon dra. Die feit dat Latyn dan die algemeen aanvaarde taal van die geleerde wêreld was, het ook bygedra dat die Lutherse teologie die Skandinawiese lande kon verower en dat die calvinisme 'n aanhang ver buite die Franssprekende wêreld in Skotland, Nederland, Duitsland, Hongarye, Pole en selfs Engeland gevind het.

Ten slotte kan gestel word dat die teologiese debat gedurende die $16^{\text {de }}$ en vroeë 17 de eeu gevoer is, een groot gemeenskaplikheid gehad het. Dit was die byna algemeen aanvaarde posisie van die Bybel. Hoewel die kerkhervormers teenoor Rome, wat naas die Bybel ook die kerklike tradisie as bron van openbaring aanvaar het, slegs die Skrif gebruik het, het dit hulle in daardie debat nie gekortwiek nie. Dit veral vanweë die feit dat die kerkhervormers 'n baie skerp onderskeid tussen die Woord van God en die mensewoord gehandhaaf het. Juis omdat die kerkhervormers die standpunt gehad het dat hulle niks meer sê as die Woord van God nie, het hulle geskrifte en uitsprake 'n duidelike gesaghebbendheid gehad wat nie dikwels weerspreek is nie.

'n Saak wat verder goed in ag geneem moet word, is dat die kerkhervormers se beoefening van die teologie gerig was op die uitbreiding, verstewiging en beskerming van die geloof van die gemeente. Dit het beteken dat hulle die volkstaal ruimskoots gebruik het, ook in hulle debatte met die sektariërs. Slegs in die gesprek met die roomse teoloë, die owerhede en die geleerde wèreld het hulle Latyn gebruik. Selfs dan nog is baie van hulle Latynse geskrifte ook in die volkstaal beskikbaar gestel. Juis so het die teologiese debat die lewe en werk van die kerk gedien en is die gelowiges daardeur opgebou in die geloof en die verstaan van die Skrif. Daaruit kan die afleiding gemaak word dat die teologiese debat wat nie weerklank vind in die lewe van die kerk nie, die geloof van die kerk nie bou nie, aan nuttelose arbeid grens.

\section{DIE TEOLOGIESE DEBAT NA DIE TYD VAN DIE KERKHERVORMING} Vir die doeleindes van hierdie verkennende oorsig is dit onmoontlik om 'n historiese oorsig te gee van die teologiese debat in Europa en miskien meer spesiaal in Nederland na die periode van die kerkhervorming. Dit enersyds omdat so 'n ondersoek geweldig uitgebreid sal wees en andersyds omdat die basiese kenmerke van die teologiese debat tog nie so baie verander het nie. 
Die volgende kan miskien dan, by wyse van 'n oorsig, gestel word. Met die dood van Calvyn in 1564 en die proklamasie van die besluite van die Konsilie van Trente op 26 Januarie 1564 deur pous Pius IV, tesame met die publikasie van die skerp anti-protestantse geloofsbelydenis van Trente (Alberigo et al 1962:636-792), het die situasie in Europa, ook danksy die optrede van die roomse owerhede, geleidelik teen die kerkhervorming gedraai. Waar die kerkhervormers tot op daardie stadium op die aanval was, groot suksesse en uitbreiding beleef het, het die roomse kerk, hervorm en gereorganiseer na Trente met die Jesuiete aan die spits, die aanval opgevang, tot stilstand gedwing en omgedraai. Dit het die protestante op die verdediging gedwing en hulle het begin om terrein af te staan (Searle 1974:165-172). Dit het die protestante na binne laat keer en geleidelik het hulle teologie staties geword en het die handhawing van posisies wat verower is, belangrik geword. Uit die aard van die saak het dit ook die teologiese debat beïnvloed.

In die calvinistiese teologie word dit dan die gebruik om die spesifiek protestantse leerstukke wat van 1517 tot 1565 na vore gekom het, in 'n omvattende dogmatiese leersisteem saam te vat. In die uitbou van die sisteem is die vorm en

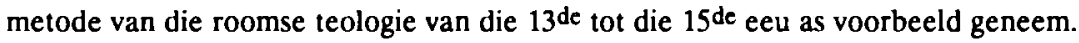
So ontstaan 'n calvinistiese skolastieke ortodoksie wat ten dienste van die kerk staan. Die doel was om 'n suiwer, sluitende dogmatiese sisteem te bou en dan kom konfessionalisme en die bestryding van die afwykende mening in die eie kring meer na vore (Muller 1987:15-22). In die debat in eie kring, veral teenoor die afwykende mening, word die leer in fyn besonderhede uitgewerk en is die liniêre, logiese denke van groot belang.

Hierdie calvinistiese ortodoksie wat dan na vore kom en basies dieselfde inhoud het in die verskillende calvinistiese lande, is die enigste standhoudende ortodoksie wat binne die raamwerk van die calvinisme ontwikkel is. Feitlik alle latere pogings om weer ' $n$ ortodoksie te vestig, is nie veel meer as 'n teruggryp of selfs net ' $n$ her-

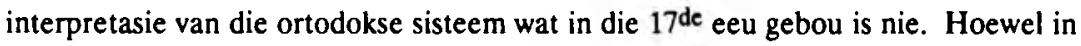
Nederland die calvinistiese ortodoksie indringend en langgerekte debatte na vore gebring het, word die teologiese debat in die tweede helfte van die $18^{\text {de }}$ eeu en selfs daarna gedomineer deur die debatte met die teoloë wat teen die vasstaande, ortodokse leersisteem gereageer het.

Tiperend hiervan is die tagtigjarige stryd wat die volgelinge van Gisbertus Voetius 1589-1676 met die volgelinge van Johannes Coccejus 1603-1669 vanaf 1658 oor die aard'en inhoud van die Sondag gevoer het. Hierdie soort debat en die voortdurende debatte tussen die ortodokse teoloë oor presiese definiëring van die leer, het 'n bepaalde kultuur van debatvoering geskep. Hierdie debatte wat in die openbaar gevoer is en waarvan die verskillende standpunte wyd gepubliseer is, het 
baie daartoe bygedra om die leer van die kerk tot in besonderhede aan die lidmate bekend te stel. Hoe breed die belangstelling was, kan afgelei word uit die feit dat $\mathrm{W}$ à Brakel se populêre dogmatiekboek, Redelyke Godtsdienst, wat in 1700 die eerste maal verskyn het, herhaaldelik herdruk is en selfs in die $19^{\text {de }}$ eeu nog herdrukke beleef het.

Tog kan van die calvinistiese skolastieke ortodoksie gesê word dat dit min nuwe insigte na vore gebring het en 'n sekere stagnasie vertoon (Nauta 1964:124-129). Selfs die biblisistiese reaksie van Coccejus en die subjektiewe reaksie van die Nadere reformasie kon in die agtiende eeu geen werklike teologiese oplewing bewerkstellig nie. Dit was miskien een van die redes waarom die skolastieke ortodoksie so weerloos was teen die mens-gesentreerde rasionalisme en die Verligtheid wat mettergaan die kerk uit sy sentrale posisie in die gemeenskap na 'n randverskynsel verskuif het. Die vergaande verwêreldliking van die Europese gemeenskap voor, tydens en na die Franse rewolusie het die teologiese debat grotendeels tot 'n binne-kerklike gebeure beperk.

In Nederland word die teologiese debat in Nederland, dit wil sê in die laat $18^{\mathrm{de}}$

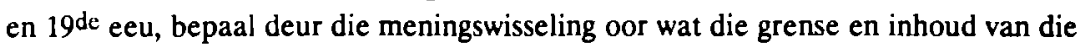
ortodoksie is en die vraag na die plek van die draagkrag van die belydenisskrif in die kerk en teologie. Dit miskien ook omdat die belydenisskrif dan nie meer waardeer word as die uitdrukking van die geloof van die gemeente nie, maar 'n norm om die suiwerheid van die leer te meet. Hier kan die invloed gesien word van die veruiterlikende, objektiverende denke wat die evangelie beskou as 'n leerstellige waarheid en die geloof as 'n kennisdaad. Daarmee het die koppeling, of te wel, die eenheid van die Woord van God en die Heilige Gees wat kenmerkend van die kerkhervormers se denke was, verlore gegaan. So word die Bybel ook verobjektiveer en in die modernisme van die 19de eeu, wat tot vandag toe deurwerk, word die Bybel en God wat Hom deur die Skrif aan die mens openbaar, van mekaar losgemaak. Dan word die Bybel gelykgeskakel met enige ander, ou menslike teks. Dan word die teologiese debat baie moeilik want dan gaan dit nie meer om die vraag wat God self in sy Woord sê nie, maar wat die navorser bepaal wat die Bybelskrywer behoort te gesê het (Vgl Baigent \& Leigh 1992:199, en veral 108. Ook Morris 1969:100-103 wat vir sy opvattings veral steun op die werk van Brandon.)

\section{SAMEVATTEND}

Die teologiese debat is, as met hierdie paar oorsigtelike historiese lyne volstaan kan word, minstens deur die eeue heen waardeer as 'n vaste en onmisbare onderdeel in die beofening van die teologie. Mettergaan het die begrip teologie egter 'n wye begrip geword wat ver buite die grense lê van wat Luther en die kerkhervormers 
onder teologie verstaan het. Luther en sy tydgenote het die indrukwekkende roomse dogmaties-kanonieke-etiese teologiese sisteem van hulle dag na die ashoop verwys. Hulle het dit vervang met die wesenlik-belangrike evangelie van die regverdigende God en die Heiland van die sondaar. Die opvolgers van die kerkhervormers het egter ook geswig vir die versoeking waaraan die Middeleeuse roomse teoloë toegegee het en so weer die evangelie op die agtergrond geskuif. So het die teologiese debat, wat sy inhoud betref, weer 'n debat oor die mens en sy vermoëns geword, ondanks die waarskuwing van die apostel Paulus (kyk 1 Kor 1:1925). Daarom is dit miskien nie vreemd dat in Nederland van die 19de eeu Kohlbrügge 'n eensame figuur was wat eintlik nie toegelaat is om aan die teologiese debat deel te neem nie (Moltmann-Wendel 1957:7). Juis dit laat die vraag ontstaan

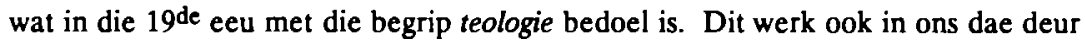
want baie wat vandag as teologie aangebied word, toon weinig verwantskap met 'n leer aangaande die lewende God wat Hom deur sy Woord aan die mens openbaar. Daarom is dit ook ' $n$ vraag of baie van die hedendaagse teologie werklik diensbaar is vir die verkondiging aan die volk van God (Vergelyk in hierdie verband die ideologies-bepaalde genitief-teologieë van die Wêreldraad van Kerke soos die teologie van die rewolusie, swart teologie en die bevrydingsteologie wat buitendien alleen moontlik is nadat die Nuwe-Testamentiese kanon drasties ingekort is.)

As die teologiese debat vandag nagegaan word, al is dit dan taamlik kursories, blyk dit dat die debat nog min of meer in diestlfde bane beweeg as ten tye van die kerkhervorming en selfs die vroeë kerk. Dan kan die volgende gestel word:

- Die debat na buite het in 'n sekere sin tot stilstand gekom of het baie van sy skerpte verloor. Die debat met Rome het so verander dat vandat die klem eerder op die gemeenskaplike geloofsbesit geplaas word as op die groot verskille wat nog steeds tussen die Bybels-reformatoriese teologie en die leer van die roomse kerk bestaan.

'n Merkwaardigheid op hierdie vlak is die geneigdheid, in die kringe van die Wèreldraad van Kerke, om die grens tussen die Christelike geloof en die heidense godsdienste te vervaag. 'n Reeks van oorsake kan hier seker aangedui word. Grondliggend bly die onrus dat in die kringe van die Wêreldraad die Heilige Skrif nie meer verstaan word as die gesaghebbende oorkonde van die openbaring van enig-lewende God nie.

- Die debat na binne, dit wil sê: binne die kring van kerke wat uit die erfenis van die kerkhervorming ontstaan het. Hierdie debat het so geweldig uitgekring dat dit nie meer oorsigtelik is nie. In 'n sekere sin hang dit met die ontwikkeling in

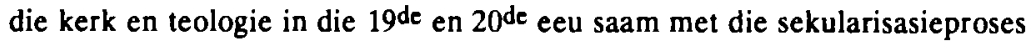
wat in die $18^{\text {de }}$ eeu begin het. Dit het minstens meegebring dat die getal kerke 
al groter geword het soos die gedagte veld gewen het dat die kerk "n godsdienstige genootskap' is, gebou op die wil en keuse van mense. Kerklike afskeidings en verdelings het moontlik geword en is deurgevoer, soms ook as die afsluiting van die kerklike en teologiese debat. Soms wil dit voorkom asof kerk en teologie die 'besit' van die mens geword het en nou deur die mens, na sy goeddunke, hanteer word.

'n Voorbeeld hiervan is die verbrokkeling van die Nederlandse Hervormde Kerk enersyds in 'n kerklike struktuur wat verskillende teologiese rigtings gehuisves het omdat die sinode geen leeruitsprake wou maak nie (Rasker 1974: 164). Andersyds moes daardie kerk twee afskeidings beleef omdat, onder andere, die teologiese debat die probleem waaroor verskil is, nie werklik kon uitpraat nie (Haitjema 1964:201).

Een van die gevolge van hierdie debat na binne was dat die begrip ortodoksie 'n negatiewe klank gekry het. Baie teoloë het teen die begrip afgegrens terwyl dit opvallend was dat baie gelowiges juis wou vashou aan vaste waardes en beskouings oor die Heilige Skrif en die inhoud van die evangelie. Opvallend is ook dat dié teoloë wat teen die ortodoksie afgegrens het, voorgestel is as die voorlopers in 'n nuwe ontwikkeling en hoog daarvoor geprys is. Dit het egter geen besondere weerklank in die kerk self gehad nie. So het daar 'n kloof gegroei tussen die wetenskaplike beoefening van die teologie, aan die een kant, en die geloof van die volk van God aan die ander kant (Rasker 1974:163). Dit het verwarring en onsekerheid geskep en daardie debat na binne tussen die partye, het ook 'n rol gespeel in die proses van ontkerkliking wat in die 19de eeu op gang gekom het. So het die teoloë 'n rol gespeel in die ontstaan, opkoms en groei van die post-Christelike heidendom (Rasker 1974:367).

Uit hierdie Nederlandse voorbeeld blyk die gevaar, op die lang duur, van 'n teologiese debat sonder grense. Immers nie alles wat in die kerk, die gemeenskap van die gelowiges, gesê en geskryf word is sondermeer aanvaarbaar nie. Die vergadering van die ampte in die kerk het die taak om oer die pura doctrina te waak en as die taak verwaarloos word, kan die kerk as gemeenskap van gelowiges ondermyn word.

In die Nederlandse kerk, byvoorbeeld, is die debat tussen Arminius en Go-

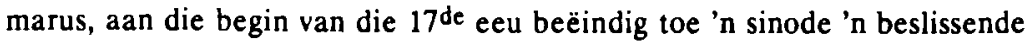
leeruitspraak na aanleiding van die debat gemaak het. In die opvolgende tyd kon dit nie weer gebeur nie omdat die kerk van die owerheid afhanklik was oor die saak van 'n byeenroep van ' $n$ nasionale sinode. Dit het in die Nederlandse kerk die gevolg gehad dat die grense van die teologiese debat nie meer duidelik getrek is nie en die vergaderings van die ampte hulle taak om die pura doctrina 
te handhaaf, van hulle agendas verwyder het. Dit het in die 19 de eeu meegebring dat die teologiese debat sonder grense die kerk as geloofsgemeenskap benadeel het.

- Opvallend is dat die gesprek na binne aanvanklik nogal kategetiese materiaal opgelewer het, veral in die kringe van die Nadere reformasie, maar dat die arbeid geleidelik afskaal. In die 19 de eeu is nuwe kategetiese publikasies nie volop nie en toon dat die teologiese debat se belangstelling in die kerk met ' $n$ taamlike klein vlammetjie gebrand het.

Samevattend kan gestel word dat die teologiese debat vanaf die tyd van die calvinistiese ortodoksie geleidelik ' $n$ egoïstiese tendens ontwikkel het. Dit gaan om die standpunt van die enkeling-teoloog wat 'n skool of groep rondom hom versamel sonder dat die doel van die teologie, die opbou van die gelowiges in hulle gehoorsaamheid aan en diens van God, in ag geneem word. So word die teologiese debat 'n saak wat vir die kerk nie altyd vreugde berei het nie.

\section{SLOTOPMERKINGS}

Aan die einde van hierdie oorsig kan miskien, baie kort, net iets gesê word oor die teologiese debat in ons kerk. Vir baie lank het die teologiese debat in ons kerklike kring beperk gebly tot 'n gesprek met die ander twee Afrikaanse kerke. Vanweë die historiese omstandighede was dit dikwels ook nie 'n gesprek nie maar eerder 'n standpuntstelling waar elkeen die eie standpunt of posisie verdedig het. Aanvanklik het dié gesprek geen vrugte opgelewer nie. Mettergaan het die aard en toon van die teologiese debat ten goede verander en het dit oorgegaan in die tussenkerklike gesprek (Pont 1993:415-425).

Miskien kan gestel word dat daar nog nie werklik 'n kultuur van gesprekvoering in ons teologiese arbeid ontwikkel het nie. In die meeste gevalle vorder dit nie veel verder as die stel van 'n bepaalde standpunt nie. Dit geld ook die binne-kerklike debat en dan ook die didaktiese aspek van daardie debat. Dit het die nadeel dat die gemeenskap van die gelowiges nie werklik by die meningswisseling betrokke raak nie, met die gevolg dat die debat ook nie verder vorder as 'n geleerde gesprek tussen teoloë nie. Juis hier bestaan die moontlikheid dat die teologie kan wegbeweeg van die belangstellingsveld van die gelowiges en verval in die gevolglike sinloosheid.

Tog moet gestel word dat die teologiese debat, as 'n vaste onderdeel van die beoefening van die teologie, 'n duidelike plek in sowel die wetenskaplike teologie as die lewe en werk van die kerk moet hê. Die teologiese debat in sy gerigtheid na buite en na binne, met sy apologetiese, tetiese en didaktiese elemente is van groot waarde ook omdat dit die gelowiges kan toerus vir hulle dienswerk. Dan is daar 
egter die voorwaarde dat die debat self die grense van die teologiese debat moet respekteer. Terselfdertyd sal die vergaderings van die ampte 'n wakende oog oor die inhoud en die sinvolheid van die debat moet hou.

So gesien kan die waarde en betekenis van die teologiese debat nie bevraagteken word nie. Inteendeel, dit moet aangemoedig word. Dan is dit egter belangrik dat daar ook besin moet word oor die grense van die debat en wat die waarde van die debat kan ondergrawe.

\section{Literatuurverwysings}

Aalders, W s a. De grote ontsporing. Den Haag: J N Voorhoeve.

Augustyn, C 1969. Kerk en belijdenis. Kampen: Kok.

Alberigo, J et al 1962. Concilionum oecumeniconum decreta. Herder: Basel.

Baigent, M \& Leigh, R 1992. The Dead Sea scrolls deception. Reading: Cox \& Wyman Ltd.

Bernhart, J (Hrsg) 1954. Thomas von Aquino: Summe der Theologie. Stuttgart: Alfred Kröner Verlag.

Von Campenhausen, H F 1956. Die Griechische Kirchenväter. Stuttgart: Kohlhammer.

Clemen, O (Hrsg) 1966. Luthers Werke in Auswahl. Berlin: Walter de Gruyter.

Graafland, C 1987. Van Calvijn tot Barth. 's-Gravenhage: Uitgeverij Boekencentrum B V.

Haas, M 1969. Huldrych Zwingli und seine Zeit. Zürich: Zwingli Verlag.

Haitjema, ThL 1964. De nieuwere geschiedenis van Neerlands Kerk der Hervorming.

's-Gravenhage: Boekencentrum.

Jacobs, P 1959. Theologie Reformierter Bekenntnisschriften in Grundzügen. Neukirchen: Neukirchener Verlag.

Kidd, B J 1911. Documents illustrative of the Continental reformation. Oxford: Clarendon Press.

Moltmann-Sendel, E 1957. Theologie und Kirche bei HF Kohlbrügge. München: Kaiser Verlag.

Morris, C 1969. Unyoung, uncoloured, unpoor. London: Epworth Press.

Marais, J A 1983. Waarheid en werklikheid. Pretoria: Aktuele Publikasies.

Muller, R A 1987. Postreformation reformed dogmatics. Grand Rapids: Baker Book House.

Nauta, D 1964. De Gereformeerde kerken in het na-reformatorisch tijdperk, in Van Itterzon, G P \& Nauta, D (red), Geschiedenis der kerk, d1, VI, 72-103. Kampen: Kok. 
Van Niftrik, G C 1953. Kleine Dogmatiek. Nijkerk: Callenbach.

Olin, J C 1966. A reformation debate. New York: Harper \& Row Publishers.

Overbeck, F 1966. Über die Anfaenge der patristischen Literatur. Darmstadt: Wissenschaftliche Buchgesellschaft.

Pont, A D 1983. 'n Man van die Woord: 'n Lewensskets van Martin Luther. Pretoria: KITAL.

- 1993. Die beweging vir kerkvereniging tussen die drie Afrikaanse gereformeerde kerkgemeenskappe in die 20ste eeu: 'n Vlugtige oorsig. In die Skriflig 27/3, 281-288.

Rasker, A J 1974. De Nederlandsche Hervormde Kerk vanaf 1795. Kampen: Kok.

Schaff, P 1919. The creeds of Christendom, Vol I. New York: Harper \& Brothers Publishers.

Schulze, L F 1971. Calvin's rephy to Pighius. Potchefstroom: Pro Rege.

Searle, G W 1974. The counter-reformation. London: U L Press.

Simpson, H W 1984. Institusie van die Christelike godsdiens deur Johannes Calvyn, Deel 1. Potchefstroom: Ejbf.

Von Campenhausen, H F 1956. Die Griechische Kirchenväter. Stuttgart: Kohlhammer. 